\title{
African Initiated Churches' potential as development actors
}

\begin{tabular}{|c|c|}
\hline \multicolumn{2}{|c|}{$\begin{array}{l}\text { Authors: } \\
\text { Philipp Öhlmann } n^{1,2} \\
\text { Marie-Luise Frost } \\
\text { Wilhelm Gräb }\end{array}$} \\
\hline \multicolumn{2}{|c|}{$\begin{array}{l}\text { Affiliations: } \\
{ }^{1} \text { Faculty of Theology and } \\
\text { School of Business and } \\
\text { Economics, Humboldt- } \\
\text { Universität zu Berlin, } \\
\text { Berlin, Germany }\end{array}$} \\
\hline \multicolumn{2}{|c|}{$\begin{array}{l}{ }^{2} \text { Department of Agricultural } \\
\text { Economics and Animal } \\
\text { Production, University of } \\
\text { Limpopo, Limpopo, } \\
\text { South Africa }\end{array}$} \\
\hline \multicolumn{2}{|c|}{$\begin{array}{l}{ }^{3} \text { Faculty of Theology, } \\
\text { Humboldt-Universität zu } \\
\text { Berlin, Berlin, Germany }\end{array}$} \\
\hline \multicolumn{2}{|c|}{$\begin{array}{l}\text { Corresponding author: } \\
\text { Philipp Öhlmann, } \\
\text { oehlmanp@hu-berlin.de }\end{array}$} \\
\hline \multicolumn{2}{|c|}{$\begin{array}{l}\text { Dates: } \\
\text { Received: } 26 \text { July } 2016 \\
\text { Accepted: } 19 \text { Aug. } 2016 \\
\text { Published: } 22 \text { Nov. } 2016\end{array}$} \\
\hline \multicolumn{2}{|c|}{$\begin{array}{l}\text { How to cite this article: } \\
\text { Öhlmann, P., Frost, M-L. \& } \\
\text { Gräb, W., 2016, 'African } \\
\text { Initiated Churches' potential } \\
\text { as development actors', HTS } \\
\text { Teologiese Studies/ } \\
\text { Theological Studies 72(4), } \\
\text { a3825. http://dx.doi. } \\
\text { org/10.4102/hts.v72i4.3825 }\end{array}$} \\
\hline \multicolumn{2}{|c|}{$\begin{array}{l}\text { Copyright: } \\
\text { (C) 2016. The Authors. } \\
\text { Licensee: AOSIS. This } \\
\text { is licensed under the } \\
\text { Creative Commons } \\
\text { Attribution License. }\end{array}$} \\
\hline \multicolumn{2}{|l|}{ Read online: } \\
\hline 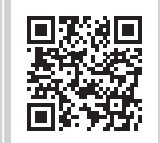 & $\begin{array}{l}\text { Scan this QR } \\
\text { code with your } \\
\text { smart phone or } \\
\text { mobile device } \\
\text { to read online. }\end{array}$ \\
\hline
\end{tabular}

African Initiated Churches (AICs) are not yet recognised as relevant actors of community development interventions. While it has been acknowledged that many of them provide coping mechanisms in adverse environments, support in social transformation and social capital, little information is available on their role as development actors. In this article, we evaluate the potential of AICs as partners of international development agencies for community development. We draw on interviews and focus group discussions with leaders of various AICs conducted in South Africa in February and March 2016. In particular, we examine the churches' understanding of development, their view on the separation of spiritual and development activities and their priorities. Moreover, we outline the development activities which they are currently engaged in and analyse the structures they have in place to do so. Our findings indicate that AICs are increasingly active in community development and offer various entry points for possible cooperation.

\section{Introduction}

In the past years there has been a growing interest in the relation between religion and development. A growing corpus of literature investigates the various aspects of this relationship (De Jong 2011; Swart 2016). At the same time, religion has moved into the focus of bi- and multilateral development institutions (Deutsche Gesellschaft für Internationale Zusammenarbeit 2015). The respective initiatives of the World Bank, the British Department for International Development, the German Federal Ministry for Economic Cooperation and Development (BMZ) and, recently, the founding of the International Partnership on Religion and Sustainable Development $(\mathrm{PaRD})$ point to the increasing recognition that religion is part of development.

Traditional Mission Churches in Southern Africa have long been active in community development. They are recognised as relevant actors by international development agencies. African Initiated Churches (AICs) lack such recognition. However, in South Africa they may well represent the majority of the population today, especially those on the margins of society. ${ }^{1}$ They have an important role in shaping the attitudes, values and ethics of their membership. Numerous studies have shown that AICs in South Africa bear a high degree of transformative potential as defined by Eisenstadt (1968:20) as 'the capacity to legitimise, in religious or ideological terms, the development of new motivations, activities, and institutions' (inter alia Mafuta 2010; Masondo 2013; Meyer 2004; Oosthuizen 1987, 1997a, 2002; Schlemmer 2008).

Taking this as a fundamental assumption undergirding our analysis, we investigated the role of AICs in South Africa as actors of community development. Deeply rooted in the communities, many AICs are already active in development work - mostly in informal ways under severe resource constraints, but with high engagement and motivation. This article, therefore, also investigates to what extent AICs bear potential as partners of national and international development agencies for community development. Vice versa, we take the perspective of the

\footnotetext{
1.According to the 2001 Census (to date the last census to include data in religion) the membership of Zionist/Apostolic/Ethiopian Churches increased from 26.6\% of the population in 1996 to 31.8\% in 2001 (Statistics South Africa 2004). Assuming the same growth rate of nearly $20 \%$ for the period from 2001 to 2016 their share would be at over $54 \%$ by now. Pentecostal-Charismatic Churches stood at $5.9 \%$ in 2001, but have since grown very dynamically (Schlemmer 2008). It can hence be safely assumed that the joint share of the population Zionist/Apostolic/Ethiopian Churches and Charismatic Churches is at well over $50 \%$. Particularly the Zionist/Apostolic/ Ethiopian Churches are often described as churches of 'the poorest of the poor' (African Independent Churches 1985:30; cf. Cross, Oosthuizen \& Clark 1993).
}

Note: This article draws on the findings of the research project 'Are African Initiated Churches adequate partners for future development cooperation?' at Humboldt-Universität zu Berlin. The project was commissioned by the German Federal Ministry for Economic Cooperation and Development, whose financial support is gratefully acknowledged. A comprehensive overview of the project results is provided in Öhlmann et al. (2016). The results were presented at the workshop of the NetACT Africa Joint Research Project on Theology and Community Development from 03 to 08 July 2016 at St Paul's University, Limuru, Kenya. The authors thank the participants of the workshop for their comments.

This article forms part of the special collection on 'Engaging development: Contributions to a critical theological and religious debate' in HTS Teologiese Studies/Theological Studies Volume 72, Issue 4, 2016. 
AICs themselves into account, by providing indications on how development cooperation needs to be structured to be relevant to the churches and their agenda of transforming believers' lives in a holistic way.

We use the term African Initiated Churches to denote all churches founded by Africans, in Africa and without direct links to 'Missionary "godfathers"' (Pobee \& Ositelu 1998:55). This includes Zionist, Apostolic and Ethiopian Churches as well as Pentecostal-Charismatic Churches. Both of these groups, which are often separated in the literature, fall into the definition of African initiated as outlined above. We subsume these churches because with very few exceptions they are not yet partners of international development agencies $^{2}$ - unlike many Mission Churches. Another common and distinctive feature is the significance of the spiritual in their cosmology, be it the Holy Spirit, spiritual forces or healing (cf. Anderson 2000). This is one of the reasons for their attraction to many people. Moreover, the differentiation is not always clear. Some churches could be qualified as belonging to the one category as well as belonging to the other. The South African Council of African Instituted Churches (CAIC), for example, includes churches that show characteristics of Charismatics and those that show characteristics of Zionists, Apostolic and/or Ethiopians. Lastly, even though Zionists, Apostolics and /or Ethiopians and Charismatics are usually differentiated in the literature, this separation is questionable. A small Zionist church with few basic structures, for example, might have more in common with a Charismatic church of similar size than with the Zion Christian Church (ZCC) which has several millions of members. The ZCC, in turn, might have more in common in terms of its structure with other transnational churches like the Redeemed Christian Church of God (RCCG) than with a small Zionist church. Hence, notwithstanding the substantial heterogeneity of the churches therein, we subsume them under the umbrella of AICs. ${ }^{3}$

The remainder of the article is organised as follows. In the second section we describe our conceptual framework as well as the research methodology and primary data. The third and fourth sections draw on the existing literature to analyse AICs' potential at the individual and social levels, respectively. The analysis of their potential at the institutional level is based on our own field research and forms the core of this article in section five. It is followed by a summary of findings in section six. Section seven highlights policy recommendations for international development agencies with respect to the cooperation with AICs. We end with concluding remarks in section eight.

\section{Conceptual framework and methodology}

The analysis is structured according to (1) the individual, (2) the social and (3) the institutional levels. The individual level refers to all aspects related to individual religiosity such as spirituality, ethics and spiritual support: What motivational and supportive factors exist in AICs and in what ways does AICs' transformational potential manifest itself? The social level refers to interaction between the church members and to the churches' relation to the wider society: What social structures exist among the church members and to what extent do these structures constitute social capital for them? To what extent are AICs politically active? The institutional level refers to the churches as institutions. What is their understanding of development and which development activities do they implement? To what extent are religiosity and development activities interrelated? Are these activities open to non-members and is there openness for cooperation with international development agencies? If so, what are areas of possible cooperation and what would be conditions for such cooperation? Of course, such categorisation is highly schematic and overlaps can be found. It should also be noted that it somewhat contradicts the holistic view of the AICs themselves. Nonetheless, while there are certain limitations, it serves the purpose of systematising the research process and results.

While the questions in areas (1) and (2) were mainly analysed on the basis of the existing literature, little research exists that explicitly deals with area (3). In this area a field study conducted in the provinces of Gauteng and Limpopo from February to March 2016 constitutes the basis of our analysis. In this framework we interviewed 14 individual church leaders, conducted 6 focus group workshops with 3 to 20 church leaders and several members of various AICs. Moreover, we conducted interviews with four key informants.

The field study followed the principles of Grounded Theory (Corbin \& Strauss 1990) and the focus group workshops were conducted using Chambers' (1994) methods of participatory rural appraisal. Mayring's (2010) methods of qualitative content analysis provided the basis of the data analysis.

\section{Individual level - Healing, spirituality and ethics}

\section{Healing}

Both the literature and our field study show that AICs' cosmology includes various elements of African spiritual realm such as the belief in spiritual forces and - in the case of the Zionist/Apostolic Churches - a strong relationship with the ancestors (Ashforth 1998; Pretorius 2004). In this worldview two types of diseases can be distinguished: 'Natural diseases' and diseases related to the spiritual world (Oosthuizen 1988:3). Beyond the mere medical meaning of the word this includes spiritual, psychological, physical and material aspects as well as social relations - in short, everything that affects the quality of life in a negative way (Pretorius 2004; Schoffeleers 1991). A central focal point of many AICs' activities, hence, is healing, which can be seen as a process to support and encourage their members to overcome conditions in their lives perceived as deficient. 
Spiritual forces, which could be dismissed as superstition from a Western perspective, are part of daily reality for many people (Oosthuizen 1997b; Pretorius 2004). It is thus fundamentally important to take this perception of the world seriously and to take it into account in the case of cooperation with AICs (Gräb 2015). In fact it is especially because of the fact that AICs, other than Mission Churches, do not reject this set of beliefs that they reach so many people. Bompani (2010) points out:

[AICs] take the negative forces within African cosmology seriously by responding to real problems as perceived [...], namely witchcraft, sorcery, and evil spirits, understanding that it is acceptable to interpret socio-economic hardships and deprivation in contemporary society within the context of adverse cosmic forces. The idea that AICs are considered experts in granting people protection and fortification against the powers of evil accounts to a large degree for their popularity and growth. (p. 309)

Generally there is consensus in the literature that the need for healing is the main reason to join an AIC (Bompani 2010; Cross et al. 1993; Pretorius 2004; Schlemmer 2008; Schoffeleers 1991; Thomas 1997). While the emphasis on spiritual healing can be problematic if it is favoured as the only remedy for physical health problems it would be rash to depict AICs as being sceptical towards modern medicine in general (Mohr 1997; Pretorius 2004). As one of the interviewed church leaders put it: 'God does not prevent you from taking a pill'.

As AICs provide concrete means to deal with the challenges, their activities are directed towards enabling their members to lead a good life (Mohr 1997). Hence, they are a strong source of agency over their own personal situation. They do not only take care of the spiritual needs of their own members (Masondo 2013; Pretorius 2004). Masondo (2013) points to the St John's Apostolic Faith Mission that offers these services irrespectively to somebody's church affiliation. Also in other churches healing and other activities are often offered to non-members. Because AICs' support to the individual is holistic, including elements of the African spiritual world view, it is particularly relevant and effective (cf. Bompani 2010).

\section{Mediators of transformation}

\section{Transformation of members' lives}

AICs' transformative potential is highly emphasised in the literature. In contexts of marginalisation and discrimination, which particularly Black people experienced during Apartheid and still experience because of persistent economic and social structures, AICs enable their members to affirm their own (positive) identity (Masondo 2013). While Black people were discriminated against by the ruling White minority, they were respected among their fellow church members and could occupy respected positions in their churches (Bompani 2010; Masondo 2005). More than 20 years after the end of Apartheid, identity and social status continue to be important features of this potential. The literature provides many examples of transformation of lives through church membership (cf. Barnard, Nell \& Mbaya 2014; Mafuta 2010; Masondo 2014; Meyer 2004; Schlemmer 2008). Notions of salvation are related to people's present lives. God is considered to have the power to provide deliverance from the adversities people face and protect them from negative spiritual forces (Barnard et al. 2014). AICs thus offer protection and support in various situations where they contribute to the stabilisation of their members' lives, equip them with resilience (Meyer 2004) and enable them to lead their lives out of their own power. In many cases this is conducive for material success, especially in the more Pentecostal/Charismatic Churches where a gospel of prosperity is preached and a high degree of selfreliance and entrepreneurship are advocated and practiced (cf. Schlemmer 2008).

\section{Ethics}

Adherence to a specific ethical code is seen as proof of successful healing and true membership of an AIC. This implies, first, the prohibition of violence, crime and drug consume; second, the prohibition of behaviours and aspects seen as detrimental to a good life, including tobacco and alcohol consume, gambling, parties and in some congregations with reference to the Old Testament consumption of pork; and third, strict sex morals (Bompani 2010; Pretorius 2004).

Far from only being restrictive AICs' ethics also include rules for social interaction. Pretorius (2004) studied ethical codes of several AICs in Cape Town. He underlines that besides adherence to the abovementioned rules, features such as love, compassion, mutual support, respect, adherence to certain biblical commandments regarding social interaction (inter alia The Ten Commandments, Rm 13:1-8; Gl 5:22; Eph $4: 17)$, honesty and peacefulness were named as most important values.

A member of the ZCC explained in what way the church enabled him to deal with his family problems:

\footnotetext{
I was having anger. Why? Because my parents were not telling me about my father. That anger was there because my mother refused to disclose what was happening between her and my father. That anger was just on me. It was not easy for me. There are these social problems that cause depression and anger. So, to guide you, to say, you must leave this and do this, that is where the church has taken a stand and said, you cannot deal with anger by drinking this [alcohol]. [...] [I]n order to deal with that anger you must get your background. [...] And that is where sometimes, spiritually, you need someone who can guide you, lead you to your culture. So that is where the church plays a role. [...] Just after you get your answers, you must forget about your past. This is where I am now. I am staying with my mother and sisters and we are happy. [...] It helps you not to have a grudge.
}

Also Schlemmer (2008) reports many church members to state that their personal relations had improved since they joined an AIC, not least because their own behaviour had changed. They were more balanced, more patient and more tolerant than before. Moreover, Bompani (2010) points out that AICs put a strong emphasis on good citizenship. 


\section{Mediators of social challenges}

Schlemmer (2008) underlines the role of the church community which supports the individual member both on a spiritual level, for example with prayers, and through solidarity, consolation and counselling. The dense social structure of AICs that provides stability and in many ways serves as a 'place to feel at home' (Welbourn \& Ogot 1966; cf. Cross et al. 1993) is a vital aspect for the individual. It is particularly important for people migrating from rural to urban areas, who constitute a substantial part of the population in many South African cities. Especially in urban contexts where people face multiple adversities and conflicts, AICs provide safe spaces. Pretorius (2004:131) describes them as "sheltered corners" in an ever changing urban milieu'. AICs offer a 'portable framework of values' as their structures simultaneously reflect those of traditional communities (Schlemmer 2008:19) and adapt them to the actual living situation (Cross et al. 1993). It is thus no coincidence that AICs often flourish in townships, which have characteristics of both rural areas and cities (Mahajan 2014). The churches empower their members to recognise and develop their own positive identity in the context of a changing society (Masondo 2005). By providing a social network of security and support AICs empower them to deal with the challenges of their living situation and to improve their lives (Mohr 1997).

There is a debate in the literature on whether AICs are fostering a mind-set directed towards modernity or whether they are backward-oriented towards tradition (cf. Bompani 2010; Gifford 2015). In our view, the tradition - modernity dichotomy is problematic as it presupposes a unidirectional movement towards a predefined modernity. Yet as Eisenstadt (2000) puts it, there is not only one but 'multiple modernities'. Hence, we refrain from taking a stance in this discussion, but note that AICs are moderators of social challenges and transformation. This is particularly relevant where social transformation is fundamental and rapid, as is the case in South Africa.

\section{Social level - Social capital and socio-political attitudes \\ Social capital}

AICs are important sources of social capital ${ }^{4}$ for their members. They are networks of mutual support undergirded by strong bonding forces and high degrees of trust (Cross et al. 1993; Masondo 2013). These networks are especially important in contexts of rural-urban migration. New arrivals benefit from the congregation in place which provides (spiritual) guidance and practical support in the new area (Cross et al. 1993). The networks also serve to mitigate risks. In the frequent case of unexpected negative events (such as deaths in the family or loss of employment)

\footnotetext{
4.We refer to social capital as defined by Bourdieu (1986:248) as 'the aggregate of the actual or potential resources which are linked to possession of a durable network of more or less institutionalised relationships of mutual acquaintance and recognition or in other words to membership to a group.' Hence social capital refers to an or in other words to membership to a group.' Hence social capital refers
individual as part of a group and not to society as a whole (cf. Portes 1998).
}

there is a high propensity to support one another (Bompani 2010; Cilliers \& Wepener 2007; Meyer 2004). Nearly every church fosters a practice of visiting and praying for sick people - often irrespectively of whether they are church members or not. Moreover, AICs provide safe spaces for their members and promote a culture of non-violence in the communities (Cross et al. 1993).

Many members of AICs form informal savings groups (so called stokvels), to which they regularly contribute a certain amount of money. The total sum will be paid to each one in turns or to all of them at the end of a certain time period, for example at the end of the year. Also burial societies, which provide financial and practical support to the organisation of a funeral, thrive among members of AICs, even though they are normally not organised by church structures. AICs are important sources of information for their members, for example about housing and employment. In Schlemmer's (2008) survey around $20 \%$ of the interviewees stated that other church members helped them to find work.

\section{African Initiated Churches and politics}

While AICs are traditionally portrayed as apolitical, recent research indicates that this hypothesis has to be differentiated (Bompani 2008; Heuser 2003; Pretorius 2004). AICs might be less involved in national political debates than Mission Churches, but they are active at local level (Bompani 2008). As part of the poorer segments of society they know the immediate needs and make them heard. According to Bompani (2008) AICs are comparable to social movements but, unlike those, do not separate religious and political areas:

Most of the church members [...] defined the religious community as a network of solidarity to fight for their proper social rights, like education, health, knowledge about HIV, economic support and housing. (p. 666)

Through the high degree of group coherence and trust AICs are conducive to collective action in the interest of their members as well as the community (Bompani 2010). This especially concerns local service delivery issues like housing, education, water and health services as well as issues such as crime and HIV, which directly affect the lives of their members. Because of their fragmentation AICs do not speak with a united voice. Nevertheless, Pretorius (2004) points out that especially in cases of joint political interest, cooperation between AICs does take place. As a form of politics 'from below' (Bompani 2010), AICs are platforms for their members to criticise state corruption and discrimination as well as to claim their rights.

\section{African Initiated Churches and gender}

AICs advocate mutual respect. Although their take on gender roles is generally conservative, they promote a healthy and peaceful family life and often take a stand against domestic violence. Nearly all AICs offer counselling specifically with regard to marriage or family problems. Pretorius (2004) notes that there were less family conflicts among the churches 
he surveyed and men tended less to beat their wives. Considering the high prevalence of domestic violence in South Africa this alone has to be acknowledged as a positive development.

Nonetheless, with regard to AICs' view on gender relations and women's position in the church neither the literature nor our field research provide clear-cut answers. It seems that heterogeneity is particularly high in this area. Some churches allow women to occupy leadership positions, others do not (Barnard et al. 2014; Pretorius 2004). Some churches, like the St John's Apostolic Faith Mission were founded by women and some (particularly smaller) churches are led by women. In most churches women cannot be church leaders but are involved in leading committees (Pretorius 2004). Especially the pastor's or bishop's wife often takes on responsibility for activities like leading the women's league and conducting certain ceremonies or services in the absence of her husband. When it comes to the role of prophets there seems to be consensus in AICs that both men and women can have this position (Pretorius 2004). The literature shows that women play an important role in the churches, even though they might not hold leading positions (Masondo 2015; Oosthuizen 1997a, 1997b). As women form the majority of active church members, Oosthuizen (1997a) points out that they are both those who build and sustain the strong network of support within the churches and those who benefit most from it.

\section{Institutional level - Notions of development and activities implemented by African Initiated Churches}

To date, little research exists about AICs and development. Examples of existing studies on AICs and development are presented in the volume by Venter (2004), in particular the study by Garner (2004). Moreover, the works by Cross et al. (1993) and Oosthuizen (1997a) provide valuable information on AICs' function for development. However, none of these studies focuses on the role they already play as actors of development in the communities they are embedded in and the institutionalised development interventions presently implemented. Consequently, comparatively little is known about their attitudes towards development and their prioritisation of different areas of development interventions. This article provides a contribution to filling this gap by illuminating the churches' role as development actors. It is mainly based on the field research conducted by the authors from February to March 2016 and can only be a starting point for a larger investigation of AICs as development actors and their potential as partners of international development cooperation.

\section{Understanding of development}

In order to understand AICs' notions of human development, interview partners were asked the open question of 'What are the major problems in people's lives?' (see Figure 1). The underlying assumption is that development describes the action directed towards the elimination of these problems. The question was one of the first questions in interviews and focus group workshops, so that the answers would not be influenced by any previous discussion.

The church leaders clearly prioritised material needs as the greatest problems. Especially the two problems mentioned most frequently, unemployment and poverty, were seen as existential challenges in people's daily lives (cf. the similar findings of Bompani 2010). It was frequently mentioned that these two can easily engender other problems such as lack of motivation, drug abuse, crime and intra-family conflicts.

However, the fact that numerous non-material aspects were named, points to a comprehensive and holistic understanding of development. Social problems such as drug and alcohol abuse, teenage pregnancies and crime were mentioned multiple times. Moreover, personal and spiritual aspects were mentioned as well. The reference to stagnancy in life and lack of motivation, the need for salvation, the lack of worship spaces or the lack of unity in the churches evidence that 'spiritual development is part of development', as one church leader phrased it.

Accordingly, the churches are trying to respond to all the needs of their members and the communities - spiritual, economic and social. Asked about how the churches supported the communities, the question was not understood in purely material sense by many AIC representatives interviewed. Rather, spiritual activities (such as Sunday school, religious programmes on community radio, praying for people, funeral services) were mentioned along with development-related activities. This further attests to the churches' comprehensive perspective on human development, according to which both the spiritual level and the material level need to be addressed. Several church leaders understood it as their Christian duty to support their members - and often also non-members - in both areas. Moreover, the activities in these two areas are closely interrelated. Church leaders are of the opinion that 'you cannot preach the gospel to a person with an empty stomach' and 'I believe that if you preach the Word it has to be made practical'. Yet another referred to John 13:35 where Jesus explains that people will recognise His disciples by the fact that they love each other and added:

And of course love is not just love. Love has to be accompanied by actions. So I think there is an interaction from what we preach to what we do. Because what we do is what we are preaching, yes: love, hope. (Jn 13:35)

In the cooperation with faith-based organisations, international development agencies normally require development-related activities to be separated from spiritual or worship activities. This was posed for discussion with the interviewees. While some thought that a separation would be possible or even helpful to reach more people, others were sceptical. Among individual interviewees seven church leaders indicated that 


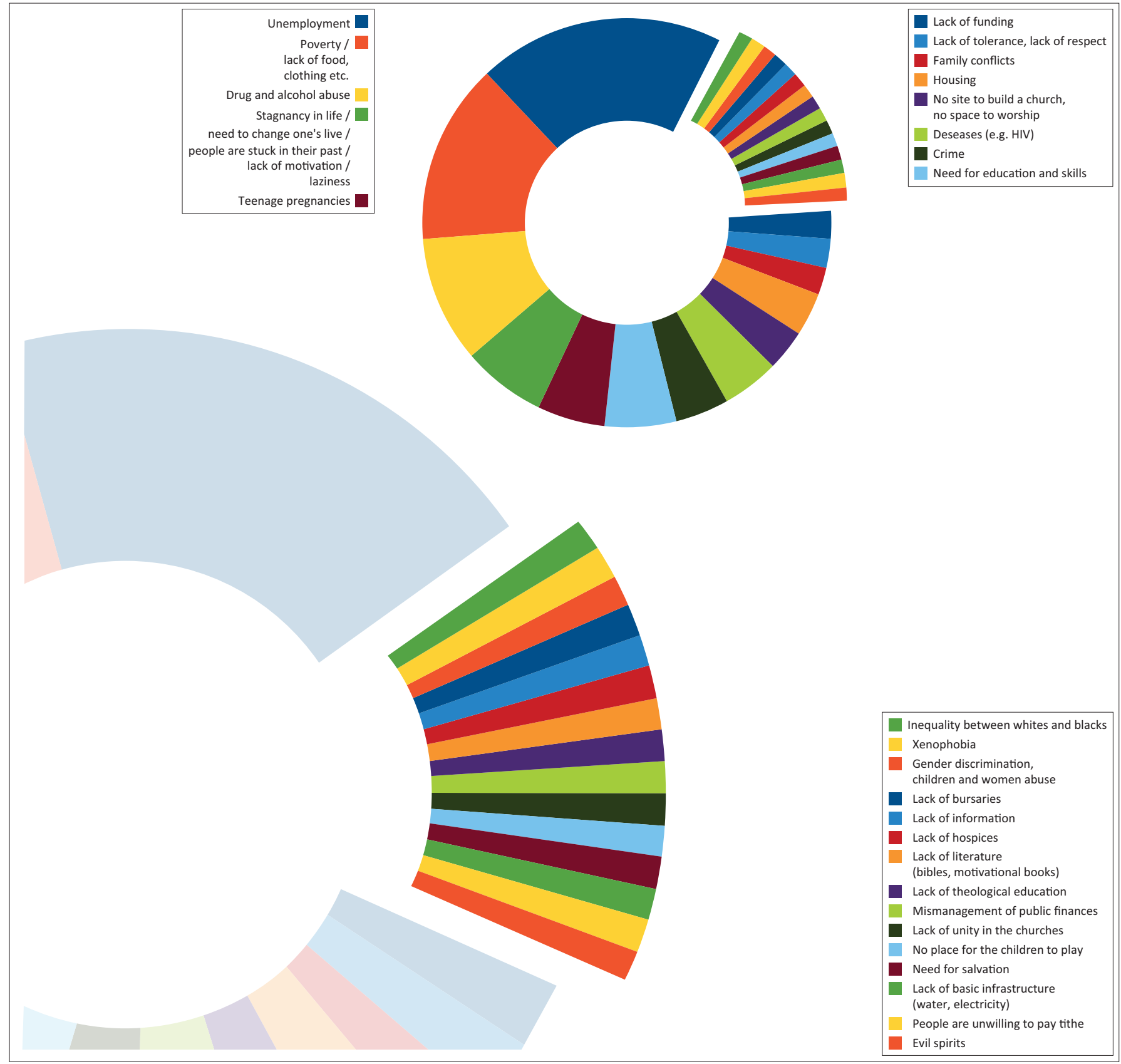

Source: Authors' own work

FIGURE 1: What are the major problems in people's lives?

such separation would be possible and seven that it would not be possible. The main argument against a separation was that people need both - in order to have a good life the spiritual and the material need to be balanced. Moreover, it was argued that in order to produce lasting effects through development interventions, it is essential to change the whole person and accompany her or him in this process of transformation. If a person does not only receive skills or a good education but also spiritual and moral guidance from the church, he or she will use these skills and knowledge for the good of others. This person's success, hence, will benefit the community. Others pointed to a practical aspect: in many cases the church building - if the church has a building at all - is the only facility available where activities could take place. Thus a complete separation between spiritual and social activities might simply not be possible because of spatial facts.

\section{Activities and target groups}

Almost all of the churches surveyed run development-related projects. They are involved in numerous activities related to the needs of their membership and the wider communities. The structure and scope of these activities vary greatly. This also reflects the heterogeneity of AICs in terms membership and structures. The most common activities implemented by the churches described are the following:

- Immediate relief related activities such as feeding schemes and donations of clothes for poor community members and homeless people are mentioned most often. 
Nine out of 14 interviewed church leaders as well as the majority of the workshop participants reported to be active in this area. This is mainly because of the fact that it is a simple activity and that it directly responds to people's needs. It is relatively easy to implement. Even small churches, for which larger activities like skills training are not feasible, can become active in the distribution of food. While it is not a development activity in the strict sense, it provides an entry point for development-related activities that may follow once the respective structures have been established. While particularly larger churches run feeding schemes on a regular basis, many smaller churches are only able to do so when funds are available or choose to do so only in cases where there is a specific need. The same applies to financial support granted to community members in need, for example, in the case of funerals. Another main focus is financial support for families unable to afford their children's school fees. In this case, funds given to the families are normally earmarked for this purpose.

- Counselling is offered in nearly all situations of life. Particularly intra-family conflicts and HIV were mentioned as most important areas of the churches counselling activities. Through counselling AICs help people to deal with adversities they experience. This activity is closely related with the spiritual support church members experience as described in section 3, but features also as institutionalised activity for members and non-members.

- Even though HIV and AIDS is often still perceived as a taboo and the stigmatisation of affected people continues to be a serious problem, awareness for the impact of the disease is very high in AICs. Several churches reported to have invited nurses to talk about health issues such as HIV and AIDS and healthy alimentation. In fact, three out of 14 church leaders underlined that lack of knowledge is a serious problem with regard to HIV and AIDS and health issues in general.

- Activities specifically targeting youth, such as music, sports, drama and youth services are implemented by more than half of the interviewed churches. More than half of the interviewed churches offer activities aimed at young people and homeless children. Several interviewees underlined that they try to get the young people from the streets to prevent them from taking drugs or getting involved in criminal activities - two aspects mentioned as major problems in people's lives.

- The focus on young people is also visible in AICs' support to education. Even though the average educational levels among members of AICs are much lower than in Mission Churches (Öhlmann 2012; Schlemmer 2008), it emerges clearly that AICs value education highly. Bursary programmes by AICs for their members reach students that in many cases have parents without an academic education (or, in fact, even with limited or no school education). A number of AICs provide bursaries to individual students at secondary or tertiary levels. The size of these bursary programmes vary from the support to individuals by the church to large-scale programmes such as the ZCC's bursary programme, which supports 300 students with an annual budget of 3 million South African rand.

- Larger AICs run their own crèches and schools. Five of the churches surveyed individually run such institutions. Church-run schools are particularly important in rural and poor areas that lack such facilities. They provide alternatives to often poor-run government primary and secondary educational institutions. These church schools and crèches are usually open to non-members. One church leader mentioned that the majority of students at his church's primary school did not belong to his church.

- Coherent with the identified need for skills, some churches also opened training centres where skills like sewing or basic computer and entrepreneurial skills are taught. Even smaller churches have become active in this area, for example by buying sewing machines and offering sewing courses at the church facilities.

- Four of the churches indicated that they run entrepreneurship and leadership training seminars for their members. This is particularly relevant because, as Schlemmer (2008) points out, a considerable percentage of South Africans are and will continue to be excluded from the formal labour market. Schlemmer also notes that government programmes often do not reach them and concludes that people are left on their own and their own initiative to improve their economic situation. Churches, therefore, play an important role in improving the socioeconomic conditions, not only by building networks of solidarity and trust in the communities, but also by supporting and accompanying people in their economic development. Here, the AICs are directly responding to what they perceive as the greatest challenges, unemployment and poverty. They seek to enable people to take initiative instead of waiting for employment opportunities to come. Church members already active in formal and informal business activities are important resource persons and multipliers. Many churches make use of this expertise and facilitate partnerships between established business people and members trying to start a business or by facilitating intra-church networks of business owners. Three out of 14 church leaders interviewed are also business owners. This relates to the connection between the entrepreneurial act of opening a church and the entrepreneurial act of starting a business described by Schlemmer (2008).

Nearly all the interviewed church leaders indicated that their activities are not exclusive for members. Especially smallscale projects like donations (food, clothing) and counselling, but also church-owned schools are open to non-members. Churches run outreach programmes that explicitly address people outside the congregation. Church members contact non-members to inform them about the church and its activities. Sometimes they also ask people about their problems and needs and provide help and support. Two church leaders whose churches are close to informal 
settlements highlighted that the congregation regularly donates food, clothing or money for school fees to the people living in the settlement.

\section{Structures}

The development-related activities of the churches are usually run by church leaders, pastors and volunteers (exceptions are teachers at church schools). While specific committees for the implementation and administration of the activities are formed, few formal and professional organisational structures for development activities (such as full-time staff) are in place. Nonetheless, interviewees expressed a high degree of willingness to professionalise and adapt the relevant structures. As mentioned, aside from the programmes run by the church as institution, some activities such as savings groups and burial societies are organised by members themselves.

Corresponding to the small-scale and voluntary character of the activities implemented, there is no systematic outcome assessment. A projects' success is largely evaluated on the basis of anecdotal evidence. However, examples given in the interviews show that on a more informal level effects are actually monitored surprisingly well. As the churches are embedded in their communities there is a close proximity to the beneficiaries of their programmes. Hence, in many cases they can follow and accompany the long-term development of the beneficiaries to which the church's assistance might have contributed (for example the educational success of a child supported financially). Responses also indicate that such information is used when considering further assistance to a person or family.

In terms of the structures in place, 7 of the 14 church leaders interviewed individually mentioned that they are registered as non-profit organisations (NPOs) with the South African Department of Social Development, most of them specifically to run development-related activities. In the focus group workshops this was also frequently mentioned. Nonetheless, few churches receive funding from outside the congregation or church for their activities. The activities are run on a small scale and only few churches have development activities that are comparable to those of NGOs and Mission Churches. Nonetheless, the AICs seem well connected. Some cooperate with local government and local businesses or have relations to other churches and NGOs. One respondent noted that his church receives groceries from local super markets which cannot be sold and distributes them to people in need.

\section{Priorities}

While the churches' representatives have hardly any experience with development funding, all interviewees expressed interest in such cooperation. The main priorities of the churches (mentioned at least by two different churches or workshop groups) in case of support by a development agency becoming available are shown in the following diagram (see Figure 2).

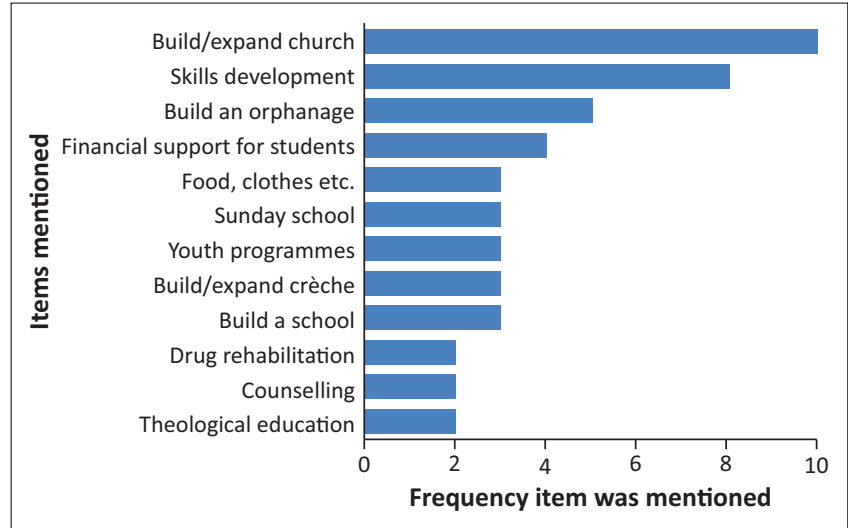

Source: Authors' own work

FIGURE 2: Churches' priorities if they could get support from international development agencies (all items mentioned at least twice, individual interviews and workshops combined). X-axis: frequency item was mentioned. Y-axis: Items mentioned.

The fact that most of the interviewees would like to build or expand their church highlights the fact that many, especially smaller and poorer congregations lack such building and gather in private dwellings, shacks or in the open to hold their services. It also highlights once more the holistic view on development of the churches. At the same time the church building is often used for both spiritual and social activities. The church is much more than a building for service and prayer. The wish to build or expand the church building therefore also reflects the wish to build up and expand the church's programmes. In light of unemployment and poverty being perceived as major problems, it is not surprising that many churches want to offer development skills. At the same time the need for sustainable impact was underlined. As one respondent pointed out: 'Do not give me a fish, teach me how to fish!'

A strong sense of accountability is present in the churches. In addition to the concrete priorities, it was often mentioned that reports would be provided, the funds would be spent according to the communities' needs and the churches would place an emphasis on accountability. Many even mentioned that any churches considered for possible cooperation should be well scrutinised beforehand to avoid misuse of funds by corrupt leaders.

Church leaders were also asked to rank five areas in which the German development agency GIZ is active in South Africa. The respondents ranked entrepreneurial skills as most important - with many noting that all areas mentioned were important. The answer was linked to the reasoning that people need skills to help themselves and to become self-sustainable, as many church leaders explicitly noted. Two church leaders suggested to add education - especially for children and young people - to the list of priorities because it provides the fundament for basic skills training (see Figures 3 and 4).

\section{Prerequisites}

During individual interviews as well as during focus group workshops, many church leaders pointed out that mutual 


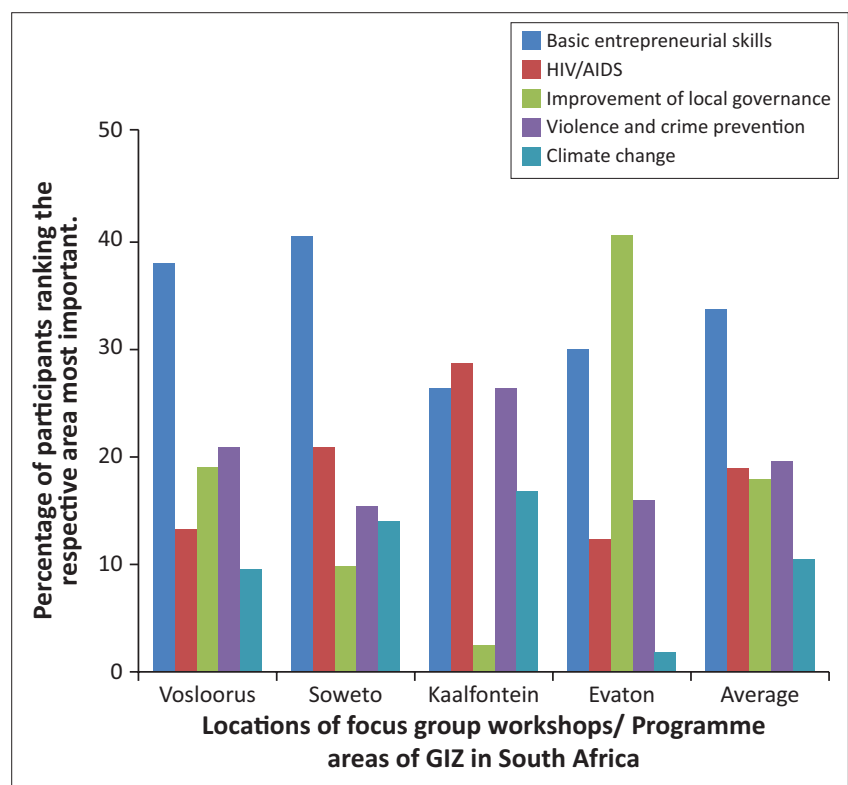

Source: Authors' own work

FIGURE 3: Percentage of workshop participants considering the respective area most important (multiple selections possible).

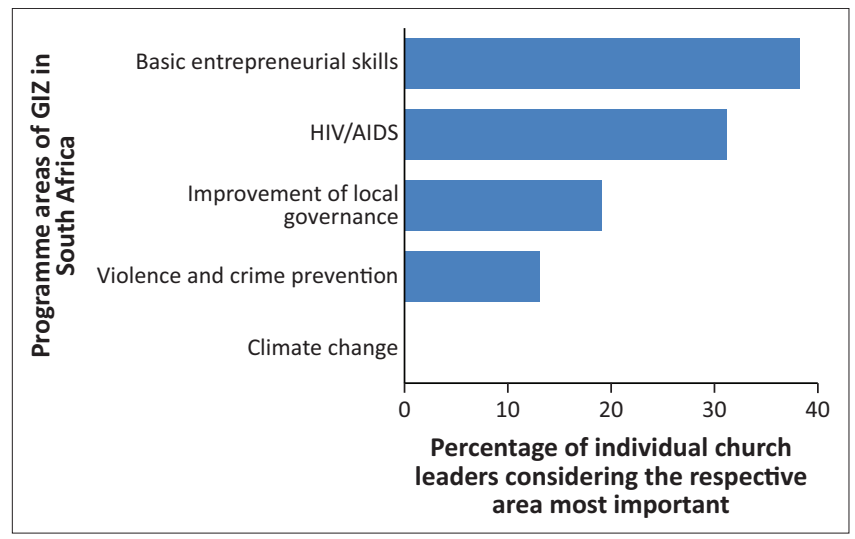

Source: Authors' own work

FIGURE 4: Percentage of individual church leaders considering the respective area most important (multiple selections possible).

respect would be the most important prerequisite to a successful cooperation. What might sound obvious at first sight is especially important in the case of AICs in South Africa. Nearly all church leaders and church members have experienced discrimination and massive oppression during the era of Apartheid. Respect was most often explicitly understood as respect for their religion and their identity as a church, as exemplified in the statement made by one of the church leaders 'Do not change me as a Christian'. The churches are well aware that certain prerequisites would inevitably have to be in place when cooperating with international development agencies, such as appropriate administrative structures and accountability. However, also on the side of development agencies there needs to be preparedness for adapting to AICs. The holistic worldview and the Christian self-understanding of these communities need to be taken seriously.

Several respondents expressed the wish for long-term sustainable cooperation and warned any potential partners not to 'make empty promises'. In fact, a number of churches have had negative experiences with official bodies. The need for transparent communication and transparent organisation was frequently stressed. Aim, scope, time frame, possible outcomes and limits of a specific project need to be clear and support-worthy to both sides. Both in the workshops and the individual interviews many respondents criticised corruption and expressed concern about the (South African) government's involvement in a possible cooperation. Emphasis was constantly placed on direct cooperation between the churches and the development agencies.

\section{Summary of findings - African Initiated Churches as partners for development cooperation?}

At the individual level, AICs provide multiple mechanisms of dealing with the challenges people experience in their daily lives. They are the source of motivation, of positive and life-affirming ethics and they provide spiritual endurance (Cilliers \& Wepener 2007) in situations of severe adversities. The fact that they cater for the spiritual cosmology of large parts of the population makes their support to the individual both highly relevant and effective. Far away from fostering passiveness and escapism from the profane world, their spirituality, activities and notions of salvation are directed towards the 'here and now' (Anderson 2000:48). Through their activities, they enable their members to gain freedom from the adverse circumstances in which they are - including material, social and spiritual aspects. Through comprehensive healing, the AICs enable their members to acquire agency over their own lives. They are mediators of transformation, both with respect to members' lives and regarding the mediation of the rapid and fundamental social change experiences by many people in developing countries.

At the social level, AICs constitute important resources of social capital. By providing networks of mutual support to those that need them most they assume a function of risk-mitigation for their members. As a source of information about many aspects of the profane and spiritual life they serve to reduce transaction costs. With respect to the attitude towards politics, the old dictum of AICs being apolitical has to be differentiated. Recent research has shown that they can be focal points of actions in the common interest of their membership towards political institutions, at least at local level. While AICs have a conservative attitude towards gender relations, they also serve as mediators of intra-family conflict and the reduction of domestic violence.

A key result of our analysis at the institutional level is that even though they receive little recognition as development actors - AICs are active in development-related activities in manifold ways. As they are deeply rooted in the community, they often know the urgent needs and problems of the people and they practically tackle these challenges wherever they can. 
While some churches are running relatively large projects, most of the activities are small-scale and informal in character. In many cases administrative structures are relatively weak and project monitoring and evaluation systems are virtually non-existent. In general, AICs have no experience with regard to international development cooperation. However, a strong will for extension and professionalisation of the activities and the build-up of the necessary administrative structures is visible.

Church leaders identify unemployment and poverty as the most crucial problems. Consequently, churches are engaged in activities that directly address the effects of these problems, for example by distributing food and clothes. Where possible AICs furthermore seek to address the causes of these problems. Many churches are active in supporting education through financial support for school fees, university bursaries or even through running their own schools and crèches. Skills training, the fostering of entrepreneurship and small business are important activities as well. Moreover, AICs provide counselling, offer activities for youth and are sources - and for many people the only sources - of information about health-related issues such as HIV.

The needs identified by the interviewees also reflect in a ranking of five areas of work of German development agency GIZ. Basic entrepreneurial skills development clearly emerges as the most important area for the churches, followed by HIV. In the case where development funding could become available to the churches, expanding or building a church is the most important priority for the churches' representatives interviewed. On the one hand, this reflects the holistic view on development, wherein spirituality and development are interrelated. On the other hand, it relates to the fact that church buildings are not merely used for worship activities, but are the central location for the churches' activities, in which development-related activities also take place. It was often mentioned that the church be expanded specifically to host such activities, for example a crèche or a skills training project.

AICs' view on development is holistic. People's needs are seen as multidimensional, including material, social and spiritual aspects. Often these dimensions cannot be separated. Moreover, their interrelatedness is a strong point for their life concepts and consequently also for their development activities. It is precisely because they see the person as a whole and include the spiritual dimension as part of development in order 'to change the whole person' (as one church leader noted) that their activities bear the potential to yield great sustainable impact in the long-term.

Hence, we conclude that international development agencies should engage with AICs. Such cooperation can be of high mutual benefit. AICs offer a platform to reach a high number of people, they know the needs of the communities, and they have already started engaging in development activities they know to be relevant for the communities. They run these activities with high initiative, but little resources.
Development cooperation could offer such resources and provide expertise for the improvement and extension of the churches' programmes. Even small and poor churches provide activities and programmes to support their members and the wider community. At present, their activities are financed through their members' contributions. Financial support from outside could increase the outreach and impact of the existing commitment. Even relatively small amounts would spark substantial initiative and activity on the side of the churches.

The above notwithstanding, international development agencies and AICs are not easily compatible and any cooperation between the two could experience challenges. Aside from the weak structures of many churches, one question is, with whom to cooperate? In South Africa, overarching associations of AICs are weak and little representative. Moreover, some churches lack financial transparency, as some church leaders pointed out. The high administrative requirements of international development agencies constitute another obstacle. At best, very large AICs would be able to fulfil them.

Nevertheless, the potential for positive change outweighs the challenges by far. Hence, we provide the following policy recommendations for development cooperation.

\section{Recommendations}

In the churches' self-understanding their religious knowledge not only has equal value as secular and scientific knowledge, but also do not distinguish between a secular and a religious sphere. Their religious knowledge is the constitutive factor of their cosmology and functions as their general frame of reference. Therefore, they also do not translate their motivations, purposes and activities expressed in a religious language to a secular, for example ethical, political or administrative language. Anyone collaborating AICs needs to be able to engage with them on their terms. This includes speaking the churches' religious language and an understanding of the belief-systems and their significance in people's daily lives. Moreover, priority-setting should be done by the churches and not by the funder. AICs are representatives of the communities and can facilitate effective development - but only if they can set the agenda.

Religion is part of development and development is part of religion. As much as German and international development cooperation recognise institutionalised religion as one among many partners for their development agenda ('religion is part of development'), it needs to be recognised that from the perspective of the AICs, as with many other religious communities, development is part of religion: That is, development from the churches' perspective is only one aspect in their transformation agenda, which aims at transforming and liberating the person and the community as physical, spiritual and social entities. Spiritual empowerment on the one hand and social and economic development on the other hand are not separated in a religious and a 
secular reality, but closely intertwined. Because of the very nature and identity of the churches this interrelatedness often cannot be disentangled. In many cases, spiritual and development aspects cannot be separated (or the churches do not want this). Moreover, it is to a large extent because of their religious knowledge and world view within a wider transformation agenda that the development work has substantial added value and long-term impact. Hence, cooperation between international development agencies and AICs should explicitly include programmes and projects in which the agency factor of the spiritual empowerment is recognised - for example religious and also critical theological formation as integral part of educational activities.

A vital aspect in strengthening the agency of the churches is not to exceed a church's capacity. Hence, we recommend programmes by churches to, wherever possible, only be cofinanced with development funds. The churches should be required to contribute themselves to their programme. This ensures ownership, relevance and accountability. In light of the limited experience in cooperation with international development agencies we recommend administrative requirements to be kept as low as possible. This requires flexibility on the part of the development agencies. Moreover, all such cooperation should be accompanied by qualification in financial management, organisational development and monitoring and evaluation - where feasible even ex ante.

Departing from these general considerations, several areas of possible partnership between development agencies and AICs can be highlighted. The churches' numerous small-scale initiatives could be a first entry-point for such cooperation. Development agencies could support these activities by establishing funds for small-scale projects. In this way, both sides could gain experience in mutual collaboration. Development agencies should also take cognisance of the churches' most important priority: the need for physical space. Development funding could be used to co-finance the construction of buildings or parts of church buildings used for development activities.

Moreover, a number of specific areas bear particular potential. Development agencies could support AIC's initiatives in the area of entrepreneurship development. In particular, they could partner with AICs in offering small business and entrepreneurship-related trainings and co-financing existing structures and activities supporting the establishment of formal and informal businesses. The same applies to churchowned training centres and schools. Development agencies could provide expertise and funding for the development of these institutions. Moreover, they could co-finance churches' bursary programmes. In light of the low levels of both tertiary education and household income among the constituencies of the AICs, this would have a high impact on poverty alleviation.

As much as education and skills training are valued by the respondents, we also noticed a high willingness among the AIC leaders themselves to further professionalise, for example in the area of counselling. Providing psychosocial support is one of the most important functions of AICs in the communities. Partnering in the training of counsellors would be a fruitful area of collaboration, which could reach large numbers of community members. One particularly important area for counselling is HIV and AIDS, the awareness for which proved to be high among the respondents. The churches are important sources of information; reaching those people who do not have access to information about medical treatment or medical services as such. Even a small church or a congregation without a church building can provide a valuable platform to inform about HIV and AIDS, as well as possible ways of prevention and cure.

Finally, AICs value ethics of good citizenship and adhere to strict ethical codes. They are important focal points of expressing the communities' needs. Some interviewees openly criticised corruption. Therefore, AICs could be partners for democracy education or corruption prevention programmes.

\section{Concluding remarks}

AICs are the fastest growing group of churches in Southern Africa. It can be safely assumed that they reach more than half of the total population. They particularly represent those who, more than 20 years into the democratic and free society of South Africa, still experience economic and social marginalisation. If development cooperation aims to reach all members of society, there is no way around the AICs. They know the communities' needs and are already active in various areas of community development, even though often on a small scale level. Hence, AICs are crucial partners for development cooperation. Moreover, the cooperation with these churches bears high potential for the transformation of the lives of many individuals and society as a whole.

\section{Acknowledgements Competing interests}

The authors declare that they have no financial or personal relationships which may have inappropriately influenced them in writing this article.

\section{Authors' contributions}

This article is based on the findings of the research project 'Are African Initiated Churches adequate partners for future development cooperation?' P.Ö. and M.-L.F. were the principal researchers. W.G. was the project leader.

\section{References}

African Independent Churches, 1985, Speaking for ourselves: Members of African Independent Churches report on their pilot study of the history and theology of their Churches, Institute for Contextual Theology, Braamfontein.

Anderson, A., 2000, Zion and Pentecost. The spirituality and experience of Pentecosta and Zionist/Apostolic Churches in South Africa, University of South Africa, Pretoria.

Ashforth, A., 1998, 'Witchcraft, violence and democracy in the New South Africa', Cahiers d'Études africaines 38(150/152), 505-532. http://dx.doi.org/10.3406/ cea.1998.1812 
Barnard, M., Nell, I. \& Mbaya, H., 2014, 'Rev Pungula Wellington Dingani: Leadership in the Corinthian Church in Phepheni, Eastern Cape, South Africa', Nederduitse Gereformeerde Teologiese Tydskrif (NGTT) 55(1), 9-28.

Bompani, B., 2008, 'African Independent Churches in Post-Apartheid South Africa: New political interpretations', Journal of Southern African Studies 34(3), 665-677. http://dx.doi.org/10.1080/03057070802259928

Bompani, B., 2010, 'Religion and development from below: Independent Christianity in South Africa', Journal of Religion in Africa 40(3), 307-330. http://dx.doi.org/10. $1163 / 157006610 \times 525435$

Bourdieu, P., 1986, 'The forms of capital', in J.G. Richardson (ed.), Handbook of theory and research for the sociology of education, pp. 241-258, Greenwood Press, New York.

Chambers, R., 1994, 'The origins and practice of participatory rural appraisal', World Development 22(7), 953-969. http://dx.doi.org/10.1016/0305-750X(94) 90141-4

Cilliers, J. \& Wepener, C., 2007, 'Ritual and the generation of social capital in contexts of poverty: A South African exploration', International Journal of Practical Theology 11, 39-55. http://dx.doi.org/10.1515/IJPT.2007.4

Corbin, J. \& Strauss, A., 1990, 'Grounded theory research: Procedures, canons, and evaluative criteria', Qualitative Sociology 13(1), 3-21. http://dx.doi.org/10.1007/ BF00988593

Cross, C., Oosthuizen, G.C. \& Clark, C., 1993, Out of the wind: The African Independent Churches and youth urbanization in Metropolitan Natal, A report prepared for the Co-operative Programme on the Youth, Durban.

De Jong, E., 2011, 'Religious values and economic growth: A review and assessment of recent studies', in G. ter Haar (ed.), Religion and development: Ways of transforming the world, pp. 111-140, Oxford University Press, New York.

Deutsche Gesellschaft für Internationale Zusammenarbeit, 2015, Status-Quo Bericht Religion und Entwicklung, Deutsche Gesellschaft für Internationale Zusammenarbeit, Eschborn.

Eisenstadt, S.N. (ed.), 1968, The Protestant ethic and modernization: A comparative view, Basic Books, New York.

Eisenstadt, S.N., 2000, 'Multiple modernities', Daedalus 129(1), 1-29.

Garner, R.C., 2004, 'African Independent Churches and economic development in Edendale', in D. Venter (ed.), Engaging modernity: Methods and cases for studying African Independent Churches in South Africa, pp. 81-103, Praeger, Westport, CT.

Gifford, P., 2015, Christianity, development and modernity in Africa, Hurst, London.

Gräb, W., 2015, 'Kultur - Religion - Entwicklung. Die Bedeutung des Verstehens von Religion als Faktor von Kultur für die Entwicklungszusammenarbeit', Entwicklungsethnologie 21(2), 165-182.

Heuser, A., 2003, Shembe, Gandhi und die Soldaten Gottes: Wurzeln der Gewaltfreiheit in Südafrika, Waxmann, Münster.

Mafuta, L., 2010, 'Religion and development in South Africa: An investigation of the relationship between soteriology and capital development in an African Initiated Church', PhD thesis, University of South Africa.

Mahajan, S., 2014, Economics of South African townships, with a special focus on Diepsloot, World Bank Studies, Washington, DC.

Masondo, S., 2005, 'The history of African Indigenous Churches in scholarship', Journal for the Study of Religion 18(2), 89-103.

Masondo, S., 2013, 'The crisis model for managing change in African Christianity: The story of St John's Apostolic Church', Exchange 42(2), 157-174. http://dx.doi. org/10.1163/1572543X-12341262

Masondo, S., 2014, 'The African Indigenous Churches' spiritual resources for democracy and social cohesion', Verbum et Ecclesia 35(3), 1-8. http://dx.doi. org/10.4102/ve.v35i3.1341
Masondo, S., 2015, 'The growth model for managing changes in African Christianity: The case of the Reformed Presbyterian Church in a Cape Town Township', Studia Historiae Ecclesiasticae 40(2), 189-206.

Mayring, P., 2010, Qualitative Inhaltsanalyse: Grundlagen und Techniken, 11th edn., Beltz, Weinheim.

Meyer, L.E.R., 2004, 'The Pentecostal movement as represented in breakthrough international an expression of Missio Dei? A contribution to an experimental pneumatology of mission', Dissertation, School of Theology, University of KwaZulu-Natal.

Mohr, M., 1997, 'Negotiating the boundary: The response of Kwa Mashu Zionists to a volatile political climate', Dissertation, University of Natal, Durban, 1993, Lit, Hamburg.

Öhlmann, P., 2012, 'He shall lift you up? The impact of religiosity on economic success in rural South Africa. Insights from a field study', Master's thesis, Faculty of Agriculture and Horticulture, Humboldt-Universität zu Berlin.

Öhlmann, P., Frost, M.-L., Gräb, W. \& Schieder, R., 2016, Sind African Initiated Churches geeignete Partner fürzukünftige Entwicklungszusammenarbeit? Wissenschaftliches Gutachten im Auftrag des Bundesministeriums für wirtschaftliche Zusammenarbeit und Entwicklung, Humboldt-Universität zu Berlin, Berlin, viewed from https:// www.theologie.hu-berlin.de/de/religion/AICs/gutachten_aics.pdf

Oosthuizen, G.C., 1987, 'The AIC and the modernisation process', Africana Marburgensia 20(1), 59-81.

Oosthuizen, G.C., 1988, 'Interpretation of demonic powers in Southern African Independent Churches', Missiology 16(1), 3-22. http://dx.doi.org/10.1177/ 009182968801600101

Oosthuizen, G.C., 1997a, African Independent Churches and small businesses: Spiritual support for secular empowerment, Human Sciences Research Council, Pretoria.

Oosthuizen, G.C., 1997b, 'Indigenous Christianity and the future of the Church in South Africa', International Bulletin of Missionary Research 21(1), 8-12. http:// dx.doi.org/10.1177/239693939702100102

Oosthuizen, G.C., 2002, 'African Independent Churches (AICS): Spiritual support for secular empowerment', Journal for Constructive Theologie 8(1), 3-11.

Pobee, J.S. \& Ositelu, G., 1998, African initiatives in Christianity: The growth, gifts and diversities of Indigenous African Churches - A challenge to the ecumenical movement, World Council of Churches, Geneva.

Portes, A., 1998, 'Social capital: Its origins and applications in modern sociology', Annual Reviews Sociology 24(1), 1-24. http://dx.doi.org/10.1146/annurev.soc.24.1.1

Pretorius, H., 2004, Drumbeats: Sounds of Zion in the Cape Flats, University of South Africa Press, Pretoria.

Schlemmer, L., 2008, Dormant capital: The Pentecostal movement in South Africa and its potential social and economic role, Centre for Development and Enterprise, Johannesburg.

Schoffeleers, M., 1991, 'Ritual healing and political acquiescence: The case of the Zionist Churches in Southern Africa', Africa: Journal of the International African Institute 61(1), 1-25. http://dx.doi.org/10.2307/1160267

Statistics South Africa, 2004, Census 2001: Primary tables 1996 and 2001 compared, Statistics South Africa, Pretoria.

Swart, I., 2016, 'Chronological bibliography on religion and development', draft paper presented at a workshop on AICs and development, University of Pretoria, Pretoria, 9th February.

Thomas, L.E., 1997, 'Constructing a theology of power: Lessons from apartheid: Anthropological reflections on healing rituals among poor Black South Africans', Missionalia 25(1), 19-39.

Venter, D. (ed.), 2004, Engaging modernity: Methods and cases for studying African Independent Churches in South Africa, Praeger, Westport, CT.

Welbourn, F.B. \& Ogot, B.A., 1966, A place to feel at home, Oxford University Press, London. 